\title{
A Comparative Analysis of the Expectations Hypothesis of the Term Structure of Interest Rates between the BRICS and G7 Countries
}

\author{
Paul-Francois Muzindutsi (iD) https://orcid.org/0000-0002-4819-8218 \\ Ph.D., Associate Professor, School of Accounting, Economics and Finance \\ University of KwaZulu-Nata, Durban, South Africa, e-mail: muzindutsip@ukzn.ac.za
}

Sinethemba Mposelwa (iD) https://orcid.org/0000-0001-6010-5849

School of Economic Sciences, North-West University, Vanderbijlpark, South Africa

e-mail:m3sine@outlook.com

\section{Abstract}

This paper examines the predictive ability of the expectations hypothesis of the term structure of interest rates in the BRICS and G7 countries by relating each country's monthly 3-month Treasury bill rate to 10-year government bond rates, from May 2003 to May 2018. The panel ARDL model, applying the mean group (MG), pooled mean group (PMG), and dynamic fixed effects (DFE) estimators, is employed to compare the short- and long-run relationships in both groups of countries. The results show that the expectations hypothesis holds in both BRICS and G7 country groups. In the long run, the short-term interest rate is able to predict the long-term interest rate in both the BRICS and G7 countries. Interest rates in BRICS indicate rapid adjustment back to the long-run equilibrium, while the adjustment is sluggish in the G7 block. Based on the findings of the study, the sluggish adjustment to the equilibrium in the G7 gives the impression that the financial crisis had an impact on the term structure of interest rates as the $\mathrm{G} 7$ countries were directly affected by the crisis.

Keywords: Expectations hypothesis, panel ARDL, G7, BRICS, term structure

JEL: E43, D92, G12 


\section{Introduction}

When a scholarly theory is flawed, it has the tendency to set the whole economy in the wrong direction (Nocera 2009). Thus, the validity of a financial or an economic theory is of vital importance since major stakeholders, especially governments and investors, rely on it (Obalade and Muzindutsi 2018). However, since the inception of the Expectation Hypothesis of interest rate structure (EH), there have been opposing views regarding its validity; thus, the theory has been at the centre of debate among academics and economists. The theory proposes that an investment that consists of a series of short-term securities should have the same returns as an investment on a longer-term security for the next holding period (Hardouvelis 1994). As such, a valid $\mathrm{EH}$ makes it possible to analyse the content on the term structure of interest rates, which may be useful for decisions related to investments and management of risk, or the analysis of future macroeconomic conditions such as the probability of a downswing in an economy (Musti and D'Ecclesia 2008). Understanding interest rate dynamics through $\mathrm{EH}$ is also essential for derivative security pricing since it depends on market rates and hedging for investment strategies (Modena 2008). It also helps in forecasting, as Mankiw and Miron (1986) affirm that the short rate is the opportunity cost of holding money; on the other hand, aggregate-spending decisions are contingent upon the long rate. Moreover, Velásquez-Giraldo and Restrepo-Tobón (2016) argued that a good forecast is essential for security pricing, financial planning, and risk management. Nonetheless, empirical evidence on EH varies as studies provide mixed results.

Despite there being no overall consensus regarding the validity of the $\mathrm{EH}$, it is necessary to test the theory in modern-day economies where the approach of monetary policy seems to vary. In the spirit of Verheyden, De Moor, and Van den Bossche (2013, p. 3), "one needs to stay critical even with respect to well-established theories, as the world is not a static environment." Therefore, this study uses different states of the world to assess the predictability of the term structure of countries that fall within two economic categories: developed and emerging economies. In particular, the Group of Seven (G7) countries represent developed nations, while emerging economies are represented by Brazil, Russia, India, China and South Africa (BRICS). The G7 bloc consists of the world's leading and most advanced economies: Canada, France, Germany, Italy, Japan, the United States, and the United Kingdom. The BRICS group consists of five of the world's major emerging market economies, which account for about two-thirds of emerging market GDP (Global Macroeconomics Team 2016).

In testing the validity of the $\mathrm{EH}$, changes in the monetary policy framework of the countries under observation, and changes in financial markets should be considered (Beechey, Hjalmarsson, and Österholm 2009). The EH has significant implications for financial development, particularly, for the newly formed BRICS bank - the New Development Bank (NDB). Features found on the term structure of interest rates provide valuable information in the future prediction of expected economic cycles within fi- 
nancial markets (Rossouw, Vermeulen and Leshoro 2014). These features may assist the NDB in attracting financial investments, and in reducing any arbitrage opportunities that may arise as a result of possible gaps found among the country rates. In addition, the information embedded in the term structure also becomes significant for various reasons (Panigrahi 1997). These reasons include the use of the information contained in the term structure by central banks as a guide to monetary policy, as outlined by Mishkin (1991) and Gurkaynak and Wright (2012).

Any comparison of these different group of nations is material, since it may reveal the effect of the global financial crisis on the term structure of interest rates between the two settings. For instance, the G7 countries were severely hit by the 2007/2008 financial crisis, and their interest rates have been significantly low (Danthine 2012). On the other hand, interest rates in the BRICS countries have been relatively high; thus, they have become an attractive alternative for investors despite their higher level of risk compared to developed nations (Magud and Sosa 2015).

Consequently, there has been a shift in monetary policy in most of the G7 countries, and the effects of the financial crisis further spread to emerging economies' term structures. For that reason, it becomes interesting to assess the validity of the EH in both settings in light of the recent financial crisis. Furthermore, in light of the low interest rates in some G7 countries currently, the study of EH may contribute towards monetary policy authorities' desire to stimulate economic activity in the affected economies by influencing the expectations of future monetary policy, as suggested by the EH (Gurkaynak and Wright 2012). In addition, the study of EH and any comparison provides market participants with the ability to predict future changes in interest rates (Modena 2008), as EH assists in the analysis of complex interest rates dynamics, thereby allowing for a better investment or risk management decision process. For instance, interest rate forecasts enable them to hedge against risks that are linked to the movement of interest rates, thereby maximizing profit opportunities from the interest rate predictions.

\section{Literature review}

The employment of interest rates to conduct monetary policy raises to prominence the role of the term structure of interest rates (Walsh 2003). The term structure spread, excluding term premiums, is a measure of monetary policy stance in relation to expectations in the long run. The $\mathrm{EH}$ is one of the oldest and well-known theories in finance and economics (Longstaff 2000). The theory dates as far back as the 1800s when it was introduced by Fisher (1896) and analysed by the likes of Macaulay (1938) and Malkiel (1966). Since then, it has gradually formed the basis for interest rate prediction and has been employed as a standard framework for the analysis of interest rates (Longstaff 2000). The EH is applicable in this study as it explicitly explains the relationship between the long rate and the short rate (Campa and Chang 1995). The theory holds that an ac- 
cumulation of the expected future short rate average is equal to the long rate (Tabak, Serra, and Cajueiro 2009). It proposes that default-free bonds are priced so that the return on a long-term bond is the same as the expected return on repeated investments of short-term bonds (Cox, Ingersoll, and Ross 1985). Thornton (2014) compares the EH to default-free Treasury debt, stating that this kind of debt is perfectly substitutable across different maturities. The theory further explains that, over time, interest rates on bonds with different maturities move together, and that investors are mostly concerned about returns over the maturity of securities (Mishkin and Eakins 2006).

By offering a complete schedule of interest rates across time, the term structure embodies the market's anticipation of future events (Cox, Ingersoll, and Ross 1985). According to the $\mathrm{EH}$, monetary policy is able to affect the long-term interest rate simply by influencing the short-term interest rates, which monetary policy is able to control, and also by altering expectations of future short-term interest rates in the market (Walsh 2003). However, the long-term interest rate is affected by more than one factor. For instance, its movement is influenced by economic activity and long-term expectations of inflation, and it is quite challenging to find a close empirical relation between the two interest rates (Estrella and Mishkin 1997). While monetary policy has a direct influence on the short-term interest rate, it tends to affect the long-term interest rate only through expectations (Estrella and Trubin 2006). Although a rise in the short-term rate is often followed by a relatively small rise in the long-term rate, this may not always be the case, as at times the long rate can move in a different direction without any coinciding movement in the short-term interest rates (Estrella and Trubin 2006). Thus, there is a limit, and the central bank is not able to have complete control over the spread between the two interest rates (Estrella and Mishkin 1996). Overall, the truism of $\mathrm{EH}$ is highly controversial.

As previously mentioned, studies of the $\mathrm{EH}$ have produced mixed outcomes, with studies conducted by MacDonald and Speight (1988) and Campbell and Shiller (1991) finding evidence in support of the theory. Further evidence supporting the theory includes studies by Batten, In, and Kim (2003), Holmes, Otero, and Panagiotidis (2011) and Thornton (2014). In the same vein, Velásquez-Giraldo and Restrepo-Tobón (2016), using one- (3-month), two- (3-month and 4-years) and three- (3-month and 4-years and 10-years) factor models, found the largest model to be the most appropriate for one- and five-day future forecasts. Similarly, Azar (2017) investigated fourteen types of securities with three months of maturity difference in the US using US T-bill yields, and they provided support for the validity of the EH for various securities. This implies the presence of informational efficiency and the absence of anomalies in the market. Ranaldo and Rupprecht (2017) studied European repurchase (repo) rates and found that the $\mathrm{EH}$ is valid when loans are secured by good collateral but violated in the presence of collateral risk. Moreover, Mwega (2014) evaluated the link between the term structure of 91- and 182-day treasury bill rates, and expected changes in expected inflation in Kenya. The study submitted that the future inflation rate can be predicted by the coefficients of the term structure. 
Conversely, some studies (Duffee 2002; Diebold and Li 2006) point out the low performance of the theory as an issue that is likely caused by the inability to forecast the direction of short-term interest rates. Hence, Assenmacher-Wesche and Gerlach (2008) contend that the rejection of the $\mathrm{EH}$ is large in data with high fluctuation in short periods, and it tends not to hold information on the future movement of interest rates. Other studies that reject the theory include those of Fama (1984) Campbell and Shiller (1991), Bekaert, Hodrick, and Marshall (2001), Clarida et al. (2006), and Sarno, Thornton, and Valente (2007). More recently, Caldeira (2017) reinvestigated the EH in Brazilian debt securities and out-of-sample predictability of excess returns using macro-variables and zero-coupon interest rates. The study rejected the $\mathrm{EH}$ throughout the whole maturity spectrum examined and submitted that excess returns can be predicted by macroeconomic variables. Further, Mallick and Mishra (2019), using twelve types of rates, rolling principal component analysis and the ARIMA model in India, found that, based on the forecasting results, different maturities of interest rate yield increases with the maturity period.

In South Africa, Iyke (2017) assessed the correlations between interest rate series of short- and long-term maturities over time using the nonlinear STAR unit root test and the asymmetric cointegration with threshold adjustment test. The study submitted that central bank policy rate and long-term government bonds yield are co-integrated although the threshold adjustment is weak, while the direction of causality flows from treasury bonds yield to bank rate. Muzindutsi and Mposelwa (2016) also found that the EH holds in South Africa with the interest rate characterised by a high speed of conversion to the equilibrium. Meanwhile, Boukhatem (2016) questioned the validity of the $\mathrm{EH}$ in explaining Tunisian government bond yield. The results of cointegrated-VAR on different pairs of yields reveals that the $\mathrm{EH}$ is invalid when medium-term maturity spectrum is considered, but it becomes valid for the long-term maturity spectrum. Hence, the validity of the EH may be relative. Moreover, Tronzano (2018) evaluated the EH in the Philippines and found that interest rates at various maturities are co-integrated but without a significant risk premium. The study suggests that the EH may be valid, but the assumption of equal proportional yields cannot be observed.

Overall, the empirical findings on $\mathrm{EH}$ have been mixed, ranging from those in support and those that reject the hypothesis, while some others maintain the middle ground. Thus, a further study on the $\mathrm{EH}$ is required to shed more light on the topic, especially in the context of economic blocks. 


\section{Methodology}

\section{Data and sample period}

The main focus of this study is on the short-term interest rate and the long-term interest rate channel, and the comparison of the relationship that exists between the two interest rates in BRICS and G7. To achieve this objective, this study employs secondary data consisting of monthly observations obtained from the 12 countries from May 2003 to May 2018. The selected period was based on the availability of data. For each of the observed countries, the study employs the 3-month Treasury-bill rate as the short-term interest rate and the 10-year government bond as the long-term interest rate, similar to Estrella and Mishkin (1998). Data employed are sourced from the Organisation for Economic Co-operation and Development (OECD) and the International Monetary Fund (IMF).

\section{Model specification}

In an effort to compare the two economic groups, the study employed the panel Autoregressive Distributed Lag (ARDL) model. The panel ARDL is advantageous because it can simultaneously estimate short- and long-run dynamics; it accommodates different orders of integration namely, (I(0), I(1) or a or mixture of $\mathrm{I}(0)$ and $\mathrm{I}(1)$ variables, but not variables integrated of order two or above; and it also accommodates a different number of lags on each variable (Shin, Yu, and Greenwood-Nimmo 2014; Kutu and Ngalawa 2016). We estimated three alternative panel ARDL approaches, namely, the Mean Group (MG), Pooled Mean Group (PMG) and Dynamic Fixed Effects (DFE) approaches. These approaches were considered because they provide consistent coefficients despite the possible presence of endogeneity as they include the lags of dependent and independent variables (Pesaran, Shin, and Smith 1999; Alsaleh and Abdul-Rahim 2019). The best estimator among the three approaches was selected based on the Hausman MG test. The general panel ARDL model is presented as follows:

$$
y_{i t}=\sum_{j=1}^{p} \phi_{i j} y_{i, t-j}+\sum_{j=0}^{q} \delta_{i j} X_{i, t-j}+\mu_{i}+\varepsilon_{i t}
$$

where $y_{i t}$ denotes the dependent variable (long-term interest rate), the number of countries is $i=1,2, \ldots n$; the periods under observation $t=1,2, \ldots, T ; k \times 1$ vector of independent variables (short-term interest rates) is denoted by $X_{i t} ; k \mathrm{x} 1$ coefficient vectors are denoted by $\delta_{i j}$; $\phi_{i j}$ symbolises the scalars while the country-specific effect $=\mu_{i}$ and $\varepsilon_{i t}$ is the error term, where $\operatorname{var}\left(\varepsilon_{i t}\right)=\sigma_{i}^{2}$. If the cointegration of variables is I(1) process in equation (1), then for all $i$ the error term is I(0) process. The co-integrated variables are assessed for their adjustment back to the equilibrium using 
the error correction term (ECT). From Equation 1, a full model with for long-run and short-run dynamics with the ECT can be derived as follows:

$$
\Delta Y_{i t}=\alpha_{1} Y_{i, t-1}-\alpha_{2} X_{i, t-1}+\sum_{j=1}^{p-1} \delta_{i j} \Delta Y_{i, t-j}+\sum_{j=0}^{q-1} \gamma_{i j} \Delta X_{i, t-i}+\mu_{t}+\varphi E C T_{i, t-1} \varepsilon_{i t}
$$

where $\varphi$ captures the speed of adjustment, $\alpha_{1}$ and $\alpha_{2}$ indicate the long-run coefficients, while $\delta$ and $\gamma$ are the short-run coefficients. To support the long-run association between the variables, the ECT coefficient should be significant and negative. It is expected that short-term interest rate shall have a directly proportional relationship with the long-term interest rate if the $\mathrm{EH}$ is valid.

\section{Unit root and other diagnostic tests}

To assess the validity of the expectations hypothesis of the two economic groups of countries, this study conducts a cointegration test, which proposes that there exists a long-run relationship between the long-term rate and the short-term rate that links the interest rates (Esteve 2006). Unit root tests were conducted to precede the cointegration tests, and the results indicate none of the variables is $I(2)$. To save space, these results are not presented in this study. Pesaran's test of cross-sectional dependence was also conducted to test for the presence of common factors affecting the cross-sectional units, and the results showed that there is no cross-sectional dependence in either block (p-value is 0.0289 for BRICS and 0.0312 for G7).

\section{Empirical analysis}

\section{Descriptive statistics}

The descriptive statistics of both the short- and long-term rates for each country are presented in Table 1 . The gap between the minimum and maximum values indicates that the long-term rates for each country have a higher value compared to that of the short-term rate. This is expected considering the higher risk which long term investors are compensated for. Also, the gap values between the interest rates of the others are not as wide as those of Brazil and Russia. This could be a reflection of the perceived lower risk, especially on the part of developed countries and the effect of the financial crisis that led to a rapid decline in interest rates. The mean values indicate that, on average, interest rates in emerging countries are higher than interest rates in developed countries, except for China. This could be due to the perceived high risk, volatile interest rate movements, and also because the interest rates in developing countries were not directly affected by the financial crisis. The long-term rates in all observed countries except for Brazil are, on average, higher than the short-term rates. This finding 
is consistent with that of Modena (2008), who found that with longer-term maturity securities, the mean tends to be higher. The short-term rates in Brazil and Russia seem to have wider spreads as measured by the standard deviation, suggesting that the short-term rates in these countries are much more volatile.

Table 1. Descriptive statistics

\begin{tabular}{|c|l|c|c|c|c|c|c|}
\hline \multicolumn{2}{|c|}{ a. Emerging Countries (BRICS) } \\
\hline \multirow{2}{*}{ Country } & Rate & Count & Min & Max & Mean & Std. Dev & Skewness \\
\hline \multirow{3}{*}{ Brazil } & Long Rate & 157 & 6.5 & 16.36 & 11.33 & 1.84 & -0.24 \\
\cline { 2 - 9 } & Short Rate & 157 & 0.19 & 24.52 & 12.51 & 4.16 & -0.22 \\
\hline \multirow{3}{*}{ Russia } & Long Rate & 157 & 6.63 & 12.58 & 8.29 & 1.31 & 1.16 \\
\cline { 2 - 9 } & Short Rate & 157 & 2.2 & 27.83 & 7.99 & 4.06 & 1.95 \\
\hline \multirow{3}{*}{ India } & Long Rate & 157 & 5.06 & 9.17 & 7.55 & 0.95 & -1.06 \\
\cline { 2 - 9 } & Short Rate & 157 & 3.18 & 10.94 & 6.65 & 1.73 & -0.29 \\
\hline \multirow{3}{*}{ China } & Long Rate & 157 & 2.81 & 4.95 & 3.67 & 0.53 & 0.38 \\
\cline { 2 - 9 } & Short Rate & 157 & -0.08 & 4.05 & 0.97 & 1.38 & 1.24 \\
\hline \multirow{2}{*}{ SA } & Long Rate & 157 & 6.37 & 10.39 & 8.40 & 0.82 & 0.31 \\
\cline { 2 - 8 } & Short Rate & 157 & 4.98 & 12.55 & 7.18 & 1.81 & 1.06 \\
\hline
\end{tabular}

\begin{tabular}{|l|l|l|c|c|c|c|c|}
\hline \multicolumn{2}{|c|}{ b. Developed Countries (G7) } \\
\hline \multirow{2}{*}{ Country } & Rate & Count & Min & Max & Mean & Std. Dev & Skewness \\
\hline \multirow{3}{*}{ Canada } & Long Rate & 157 & 1.12 & 4.93 & 3.17 & 1.08 & -0.20 \\
\cline { 2 - 8 } & Short Rate & 157 & 0.38 & 5.12 & 2.02 & 1.34 & 0.73 \\
\hline \multirow{3}{*}{ France } & Long Rate & 157 & 0.44 & 4.73 & 3.07 & 1.15 & -0.81 \\
\cline { 2 - 9 } & Short Rate & 157 & -0.25 & 5.11 & 1.68 & 1.52 & 0.73 \\
\hline \multirow{3}{*}{ Italy } & Long Rate & 157 & 0.12 & 4.56 & 2.70 & 1.31 & -0.46 \\
\cline { 2 - 8 } & Short Rate & 157 & -0.25 & 5.11 & 1.68 & 1.52 & 0.73 \\
\hline \multirow{3}{*}{ Japan } & Long Rate & 157 & 1.29 & 7.06 & 4.03 & 1.12 & -0.64 \\
\cline { 2 - 8 } & Short Rate & 157 & -0.25 & 5.11 & 1.68 & 1.52 & 0.73 \\
\hline \multirow{2}{*}{ UK } & Long Rate & 157 & -0.12 & 1.96 & 1.10 & 0.49 & -0.48 \\
\hline \multirow{2}{*}{ US } & Short Rate & 157 & 0.06 & 0.89 & 0.34 & 0.24 & 0.93 \\
\cline { 2 - 8 } & Long Rate & 157 & 1.59 & 5.43 & 3.55 & 1.17 & -0.24 \\
\cline { 2 - 8 } & Short Rate & 157 & 0.48 & 6.58 & 2.55 & 2.17 & 0.41 \\
\cline { 2 - 8 } & Long Rate & 157 & 1.50 & 5.11 & 3.29 & 1.05 & -0.05 \\
\hline
\end{tabular}

Source: International Monetary Fund (2018) and Organisation for Economic Co-operation and Development (2018).

\section{Panel results}

The cointegration test for emerging economies and developed economies are presented in Table 2 and Table 3, respectively. Before interpreting the results, the Hausman MG test was used to decide the appropriate estimator between the MG, PMG and DFE. 


\section{Emerging economies results}

Table 2 presents an ARDL cointegration test that is estimated at a constant level and the selected model (based on the Akaike Information Criterion). In the long-run equation, the p-value of the Hausman test is greater than 0.05, the Ho that the PMG estimator is efficient and consistent cannot be rejected. Thus, the PMG long-run results are interpreted. The results in Table 2 provide strong evidence of cointegration between the long and short-term interest rates in the emerging economies. The long-run equation is given by the statistically significant short-term rate coefficient of 0.197749 , thus implying there exists a positive long-run relationship between the variables in the emerging economies. A change in the short-term interest rate will lead to a rise in the long-term interest rate of 19.77 percent in the long run.

Hence, the Hausman test compared the MG to DFE short-run estimators and the p-value of the Hausman MG test that is less than 1 percent, suggest that the short-run MG estimators are more suitable. The ECT coefficient of -0.076853 implies that there is an adjustment of approximately 7.69 percent back to equilibrium each month. Accordingly, it takes about 13.01 (1/0.076853) months for changes in the short-term interest rate to have a full effect on the long-run interest rate and thus restore the deviation back to the equilibrium state. This adjustment is rather lengthy, and it suggests that the short-run relationship between the long term and the short-term interest rates is not strong in the BRICS block.

Table 2. Panel ARDL results - emerging economies

\begin{tabular}{|l|l|c|l|l|l|l|l|}
\cline { 2 - 8 } \multicolumn{1}{c|}{} & \multicolumn{2}{c|}{ MG } & \multicolumn{2}{c|}{ PMG } & \multicolumn{2}{c|}{ DFE } \\
\cline { 2 - 8 } \multicolumn{1}{c|}{} & Variable & Coeffic. & P-Values & Coeffic. & P-Values & Coeffic. & P-Values \\
\hline $\begin{array}{l}\text { LR } \\
\text { Equation }\end{array}$ & SR & 0.2315 & 0.0235 & 0.197749 & 0.0009 & 0.20193 & 0.0012 \\
\hline \multirow{4}{*}{$\begin{array}{l}\text { SR } \\
\text { Equation }\end{array}$} & ECT & -0.07685 & 0.0000 & -0.07756 & 0.0071 & -0.07976 & 0.0089 \\
\cline { 2 - 8 } & $\mathrm{D}(\mathrm{LR}(-1))$ & 0.19137 & 0.0000 & 0.1916 & 0.0002 & 0.19201 & 0.0003 \\
\cline { 2 - 8 } & $\mathrm{D}(\mathrm{LR}(-2))$ & 0.00198 & 0.9740 & 0.00210 & 0.9371 & 0.00201 & 0.9280 \\
\cline { 2 - 8 } & $\mathrm{D}(\mathrm{SR})$ & 0.08587 & 0.1064 & 0.09612 & 0.1101 & 0.08497 & 0.1059 \\
\cline { 2 - 8 } & $\mathrm{C}$ & 0.48954 & 0.0000 & 0.47811 & 0.0003 & 0.49162 & 0.0001 \\
\hline L R: Hausman & MG test, p-value $=0.219$ S R: Hausman MG test, $p$-value $=0.009$ & \\
\hline
\end{tabular}

Source: International Monetary Fund (2018) and Organisation for Economic Co-operation and Development (2018).

Furthermore, the short-term interest rate coefficient of 0.085873 indicates that a change in the short-term interest rate leads to a positive change in the long-term interest rate in the short run. However, this coefficient is not statistically significant. Thus, the statistical insignificance of the short-term interest rate implies that, in the short run, the long-term interest rate does not respond to changes in the short-term rate. However, an increase in the long-term interest rate in the previous periods positively influences the long-term interest rate in the short run. Specifically, a change in the lag of long-term interest rate in the short run leads to a 19.13 percent increase in the long rate. The long rate that is lagged twice, on the other hand, is not statistically significant. 


\section{Developed economies results}

For developed countries, the Schwarz Information Criterion (SIC) is used for optimal lag selection as it has the lowest value, and the selected model is $(2,1)$. The ARDL cointegration test is estimated with a constant, and the outcome is presented in Table 3. For the long-run estimates, the p-value of the Hausman test is greater 0.05 , the Ho that the PMG estimator is efficient and consistent cannot be rejected. Thus, the PMG long-run results are interpreted. The long-run equation of the developed countries implies that there is a strong positive relationship between the observed variables in the long-run as the short-term interest rate coefficient is statistically significant at 1 percent. An increase in the short-term rate will lead to a rise in the long-term rate of 47.32 percent in the long run.

Table 3. Panel ARDL results - developed countries

\begin{tabular}{|l|l|c|c|c|c|c|c|}
\cline { 3 - 8 } \multicolumn{1}{c|}{} & \multicolumn{2}{c|}{ PG } & \multicolumn{2}{c|}{ PMG } & \multicolumn{2}{c|}{ DFE } \\
\hline \multirow{2}{*}{$\begin{array}{l}\text { LR } \\
\text { Equation }\end{array}$} & Variable & Coeffic. & P-Values & Coeffic. & P-Values & Coeffic. & P-Values \\
\hline \multirow{4}{*}{$\begin{array}{l}\text { SR } \\
\text { Equation }\end{array}$} & 0.48416 & 0.0010 & 0.47329 & 0.0000 & 0.469211 & 0.0009 \\
& ECT & -0.02483 & 0.0000 & -0.02761 & 0.0010 & -0.03015 & 0.0008 \\
\cline { 2 - 8 } & $\mathrm{D}(\mathrm{LR}(-1))$ & 0.23913 & 0.0000 & 0.2132 & 0.0005 & 0.19201 & 0.0003 \\
\cline { 2 - 8 } & $\mathrm{D}(\mathrm{SR})$ & 0.17027 & 0.0000 & 0.16810 & 0.0010 & 0.15934 & 0.0002 \\
\cline { 2 - 8 } & $\mathrm{C}$ & 0.05012 & 0.0009 & 0.04921 & 0.0011 & 0.04870 & 0.0010 \\
\hline \multicolumn{2}{|l|}{ L R: Hausman MG test, p-value $=0.341$ S R: Hausman, MG test, $p$-value $=0.012$} & \\
\hline
\end{tabular}

Source: International Monetary Fund (2018) and Organisation for Economic Co-operation and Development (2018).

For the short-run equation, the Hausman test is used to compare the PG and DFE estimators. Since the p-value of the Hausman test is statistically significant at the 1 percent level of significance, the short-run MG estimators are more suitable. The results indicate that there is correction back to equilibrium in the short run as the ECT is negative and statistically significant, as desired. The -0.024825 coefficient means that roughly 2.48 percent of deviations from equilibrium are corrected every month. Thus, changes in the short-term interest rate take 40.28 months $(1 / 0.024825)$ to have a full effect on the long-term rate. This suggests that the adjustment towards equilibrium is sluggish in developed countries. Furthermore, in the short-run, changes in the short-term interest rate and long-term interest rate in the previous period, have a significant and increasing effect on the long-term interest rate. They lead to a 17.03 and 23.91 percent increase in long-term interest rate, respectively.

\section{Discussion}

Using panel data estimation methods, the BRICS and G7 countries are pooled accordingly, and the findings are similar in both groups, especially in the long- run. As with most tests for cointegration, a unit root test is conducted to check whether or not the series 
are stationary. Cointegration for both groups is confirmed by the significant coefficient in the long-run equation. The short-run effects, on the other hand, differ between the two groups. The long-term interest rate does not respond to changes in the short-term interest rate when BRICS are pooled together in the short-run. However, the long-term interest rate does respond to changes in the short-term interest rate in G7.

There is a vast amount of difference in the speed of the adjustment to the equilibrium and its behaviour between the two groups. For emerging economies, the full adjustment of 13.01 months is relatively lengthy, although it is faster than that of developed countries where adjustment back to equilibrium is sluggish at 40.28 months. These findings suggest that a shock in the short-term interest rate has a quicker and larger effect on the long-term interest rate in emerging economies than developed countries.

Given the backdrop of global financial interdependence in the markets, overall, the results indicate that there is co-movement in the term structure of interest rates among developed countries. This outcome is not surprising given the integration of financial markets and central banks, particularly in Europe. Major events in developed countries have led to a shift in the conduct of monetary policy, with the employment of non-conventional monetary policy methods. Zero bound and negative interest rates in the United States and the euro area, respectively, led to the inflow of capital in emerging economies since interest rates remained relatively higher in emerging economies compared to developed countries. The results in both blocks suggest that the central bank is able to influence the long-term interest rate by changing the short-term interest rate. This is consistent with the studies conducted by Walsh (2003), Bonga-Bonga (2012) and Thornton (2014).

Emerging economies, on the other hand, are not immune to the major events that occurred in developed countries; the term structure of interest rates in emerging economies seems to have merely reacted to the effects of the financial crisis. The results indicate the impact of global financial integration in the markets on the observed countries' term structures. There is significant evidence suggesting that domestic term structures of interest rates are influenced by foreign monetary policy and foreign term structures as a consequence of integration and liberalization of financial markets (Holmes, Otero, and Panagiotidis 2011). Since long-term government bonds provide a safe haven for investors in times of uncertainty in financial markets (Bernanke 2013), the capital inflows that surged in emerging economies post the financial crisis following the uncertainty in the developed countries provide evidence of this feature. This is in agreement with the study of Holmes, Otero, and Panagiotidis (2011), where domestic term structures of interest rates are influenced by foreign monetary policy and foreign term structures as a consequence of integration and liberalization of financial markets. 


\section{Concluding remarks}

This paper examines the validity of the expectations hypothesis in two economic groups of countries, namely, the BRICS and the G7, and it also investigates the predictability of the term structure of interest rates. Using the panel ARDL, the results show that the expectations hypothesis holds in both BRICS and G7 country groups. This means that the short-term interest rate can be used to predict the long-term interest rate in both the BRICS and G7 countries. The interesting finding of this study is that the interest rates in BRICS indicate rapid adjustment back to long-run equilibrium; while the adjustment is sluggish in the G7 block. The implication of this finding is that the central bank is able to influence the long-term interest rate by changing the short-term interest rate, thereby affecting economic activity via the response of the long-term interest rate. Thus, the short-term interest rate has a greater effect in the emerging economies than the developed ones, suggesting that the use of short-term interest as a tool to influence economic activity is likely to be more successful in emerging economies as opposed to developed countries.

The finding in this paper is thus consistent with the implication of the $\mathrm{EH}$, as the short-term interest rate is found to be an important component in the interest rate dynamics. The validity of the expectations hypothesis in the analysis also proved that the theory is still valuable for the analysis of interest rates. It is able to assist market participants to predict the future direction of interest rates using the term structure of interest rates. This study assumes a constant relationship throughout the sample period, but this may not always be the case. Thus, future research could explore whether or not the EH changes with the changes in economic or market conditions. Additionally, a re-examination of the EH dynamics during the period of COVID-19 may shed more light on the topic.

\section{References}

Alsaleh, M., Abdul-Rahim, A.S. (2019), Financial Development and Bioenergy Consumption in the EU28 Region: Evidence from Panel Auto-Regressive Distributed Lag Bound Approach, "Resources”, 8 (1), pp. 1-13, https://doi.org/10.3390/resources80 10044

Assenmacher-Wesche, K., Gerlach, S. (2008), The Term Structure of Interest Rates across Frequencies, European Central Bank, "Working Paper Series", No. 976.

Azar, S.A. (2017), The Pure Expectations Theory and Quarterly Interest Rate Premiums, "Accounting and Finance Research", 7 (1), pp. 161-178, https://doi.org/10.54 30/afr.v7n1p161

Batten, J., In, F., Kim, S. (2003), What Drives the Term and Risk Structure of Japanese Bonds?, "The Quarterly Review of Economics and Finance”, 43 (3), pp. 518-541, https://doi.org/10.1016/S1062-9769(02)00193-X 
Beechey, M., Hjalmarsson, E., Österholm, P. (2009), Testing the Expectations Hypothesis When Interest Rates Are Near Integrated, "Journal of Banking \& Finance", 33 (5), pp. 934-943, https://doi.org/10.1016/j.jbankfin.2008.10.008

Bekaert, G., Hodrick, R.J., Marshall, D.A. (2001), Peso Problem Explanations for Term Structure Anomalies, "Journal of Monetary Economics", 48 (2), pp. 241-270, https:// doi.org/10.1016/S0304-3932(01)00075-7

Bernanke, B.S. (2013), Long-Term Interest Rates. 1 Mar, "Annual Monetary/Macroeconomics Conference”, The Past and Future of Monetary Policy, San Francisco.

Bonga-Bonga, L. (2012), Budget Deficit and Long-Term Interest Rates in South Africa, “African Journal of Business Management”, 6 (11), pp. 3954-3961, https://doi.org /10.5897/AJBM11.713

Boukhatem, J. (2016), Does The Expectations Hypothesis Explain The Term Structure Of Treasury Bond Yields In Tunisia?, “The Journal of Applied Business Research”, 32 (1), pp. 239-254, https://doi.org/10.19030/jabr.v32i1.9535

Caldeira, J.F. (2017), Investigating the expectation hypothesis and the risk premium dynamics: new evidence for Brazil, "Empirical Economics", pp. 1-18, https://doi.org /10.2139/ssrn.3317047

Campa, J., Chang, P.K. (1995), Testing the Expectations Hypothesis on the Term Structure of Volatilities in Foreign Exchange Options, "The Journal of Finance", 50 (2), pp. 529-547, https://doi.org/10.1111/j.1540-6261.1995.tb04794.x

Campbell, J.Y., Shiller, R. (1991), Yield Spreads and Interest Rate Movements: A Bird's Eye View, "Review of Economic Studies", 58 (3), pp. 495-514, https://doi.org/10.23 07/2298008

Clarida, R.H., Sarno, L., Taylor, M.P., Valente, G. (2006), The Role of Asymmetries and Regime Shifts in the Term Structure of Interest Rates, "The Journal of Business", 79 (3), pp. 1193-1224, https://doi.org/10.1086/500674

Cox, J.C., Ingersoll, J.E., Ross, S.A. (1985), A Theory of the Term Structure of Interest Rates, "Econometrica”, 53 (2), pp. 385-407, https://doi.org/10.2307/1911242

Danthine, J.P. (2012), A World of Low Interest Rates, 22 March, Swiss National Bank, Zurich (Speech).

Diebold, F.X., Li, C. (2006), Forecasting the term structure of government bond yields, "Journal of Econometrics", 130 (2), pp. 337-364, https://doi.org/10.1016/j.jeconom .2005.03.005

Duffee, G.R. (2002), Term Premia and Interest Rate Forecasts in Affine Models, "The Journal of Finance", 57 (1), pp. 405-443, https://doi.org/10.1111/1540-6261.00426

Esteve, V. (2006), A Note on Nonlinear Dynamics in the Spanish Term Structure of Interest Rates, "International Review of Economics and Finance", 15 (3), pp. 316-323, https://doi.org/10.1016/j.iref.2004.11.008

Estrella, A., Mishkin, F.S. (1996), The Yield Curve as a Predictor of U.S. Recessions, "Current Issues in Economics and Finance", 2 (7), pp. 1-6, https://doi.org/10.2139 /ssrn.1001228

Estrella, A., Mishkin, F.S. (1997), The Predictive Power of the Term Structure of Interest Rates in Europe and the United States: Implications for the European Central Bank, "European Economic Review", 41 (7), pp. 1375-1401. 
Estrella, A., Mishkin, F.S. (1998), Predicting US Recessions: Financial Variables as Leading Indicators, "Review of Economics and Statistics", 80 (1), pp. 45-61, https://doi .org/10.1162/003465398557320

Estrella, A., Trubin, M.R. (2006), The Yield Curve as a Leading Indicator: Some Practical Issues, "Current Issues in Economics and Finance", 12 (5), pp. 1-7.

Fama, E.F. (1984), The Information in the Term Structure, "Journal of Financial Economics", 13 (4), pp. 509-528, https://doi.org/10.1016/0304-405X(84)90013-8

Fisher, I. (1896). Appreciation and Interest. "The Economic Journal”, 6 (24), pp. 567570, https://doi.org/10.2307/2957188

Global Macroeconomics Team (2016), Global Weekly: Sources of the Growth Slowdown in BRICS, https://blogs.worldbank.org/prospects/global-weekly-sources-growth-sl owdown-brics (accessed: 24.04.2016).

Gurkaynak, R.S., Wright, J.S. (2012), Macroeconomics and the Term Structure, "Journal of Economic Literature”, 50 (2), pp. 331-367, https://doi.org/10.1257/jel.50.2.331

Hardouvelis, G.A. (1994), The Term Structure Spread and Future Changes in Long and Short Rates in the G7 Countries: Is There a Puzzle?, "Journal of Monetary Economics”, 33 (2), pp. 255-283, https://doi.org/10.1016/0304-3932(94)90003-5

Holmes, M.J., Otero, J., Panagiotidis, T. (2011), The Term Structure of Interest Rates, the Expectations Hypothesis and International Financial Integration: Evidence from Asian Economies, "International Review of Economics and Finance", 20 (4), pp. 679689, https://doi.org/10.1016/j.iref.2010.11.021

International Monetary Fund (IMF) (2018), The International Financial Statistics database, https://data.imf.org/?sk=4c514d48-b6ba-49ed-8ab9-52b0cla0179b\&sId=14 09151240976 (accessed: 8.07.2018).

Iyke, B.N. (2017), On the term structure of South African interest rates: Cointegration and threshold adjustment, "International Journal of Sustainable Economy", 9 (4), pp. 300-321, https://doi.org/10.1504/IJSE.2017.10007333

Kutu, A.A., Ngalawa, H. (2016), Dynamics of industrial production in BRICS countries, "International Journal of Economics and Finance Studies", 8 (1), pp. 1-25.

Longstaff, F.A. (2000), Arbitrage and the Expectations Hypothesis, "The Journal of Finance", 55 (2), pp. 989-994, https://doi.org/10.1111/0022-1082.00234

Macaulay, F.R. (1938), Some Theoretical Problems Suggested by the Movements of Interest Rates, Bond Yields, and Stock Prices in the United States since 1856, "NBER Working Paper Series", New York.

MacDonald, R., Speight, A.E. (1988), The Term Structure of Interest Rates in the UK, "Bulletin of Economic Research", 40 (4), pp. 287-300, https://doi.org/10.1111/j.1467 $-8586.1988 . t b 00272 . \mathrm{x}$

Magud, N., Sosa, S. (2015), Investment in Emerging Markets: We Are Not in Kansas Anymore... Or Are We?, "IMF Working Paper", 15 (77), pp. 4-26, https://doi.org/10 $.5089 / 9781475534221.001$

Malkiel, B.G. (1966), The Term Structure of Interest Rates, Princeton University Press, Princeton, https://doi.org/10.1515/9781400879786

Mallick, A.K., Mishra, A.K. (2019), Interest rates forecasting and stress testing in India: a PCA-ARIMA approach, "Palgrave Communication", 5 (32), pp. 1-17, https://doi .org/10.1057/s41599-019-0236-7 
Mankiw, N.J., Miron, J.A. (1986), The Changing Behaviour of the Term Structure of Interest Rates, “The Quarterly Journal of Economics”, 101 (2), pp. 211-228, https://doi .org/10.2307/1891113

Mishkin, F.S. (1991), A Multi-Country Study of the Information in the Term Structure about Future Inflation, "Journal of International Money and Finance", 10 (1), pp. 2-22, https://doi.org/10.1016/0261-5606(91)90024-E

Mishkin, F.S., Eakins, S.G. (2006), Financial Markets and Institutions, Pearson Education, India.

Modena, M. (2008), The Term Structure and the Expectations Hypothesis: a Threshold Model, MPRA Paper No. 9611, http://mpra.ub.uni-muenchen.de/9611 (accessed: 20.05.2018).

Musti, S., D’Ecclesia, R.L. (2008), Term Structure of Interest Rates and the Expectation Hypothesis: The Euro Area, "European Journal of Operational Research"”, 185 (3), pp. 1596-1606, https://doi.org/10.1016/j.ejor.2006.08.034

Muzindutsi, P.F., Mposelwa, S. (2016), Testing the Expectations Hypothesis of the Term Structure of Interest Rates in BRICS Countries: A Multivariate Co-integration Approach, "Acta Universitatis Danubius. Economica”, 12 (4), pp. 289-304.

Mwega, F.M. (2014), A Note On Term Structure And Inflationary Expectations In Kenya, Paper presented at a Central Bank of Kenya (CBK) Technical Retreat in Naivasha, Kenya, held on June 13-14.

Nocera, J. (2009), Poking holes in a theory on markets, “The New York Times”, http:// www.nytimes.com/2009/06/06/business/06nocera.html?_r=1\&scp=1 (accessed: 18.06.2018).

Obalade, A.A., Muzindutsi, P.F. (2018), Return predictability and market conditions: evidence from Nigerian, South African and Mauritian stock markets, "African Journal of Business and Economic Research", 13 (2), pp. 7-23, https://doi.org/10.31920 /1750-4562/2018/v13n2a1

Organisation for Economic Co-operation and Development (OECD) (2018), OECD Data, https://data.oecd.org (accessed: 15.07.2018).

Panigrahi, M.S. (1997), Term Structure and Economic Activity, "Economic and Political Weekly", 32 (42), pp. 2661-2666.

Pesaran, M.H., Shin, Y., Smith, R.P. (1999), Pooled Mean Group Estimation of Dynamic Heterogeneous Panels, "Journal of the American Statistical Association", 94 (446), pp. 621-634, https://doi.org/10.1080/01621459.1999.10474156

Ranaldo A., Rupprecht, M. (2017), Explaining the Failure of the Expectations Hypothesis with Short-Term Rates, "Working paper on Finance", University of St. Gallen, https://doi.org/10.2139/ssrn.2851804

Rossouw, J.J., Vermeulen, J.C., Leshoro, L.A., (2014). Monetary Economics in South Africa, 2nd Ed., Van der Merwe, E., Mollentze, S., Oxford University Press, Cape Town.

Sarno, L., Thornton, D.L., Valente, G. (2007), The Empirical Failure of the Expectations Hypothesis of the Term Structure of Bond Yields, "The Journal of Financial and Quantitative Analysis”, 42 (1), pp. 81-100.

Shin, Y., Yu, B., Greenwood-Nimmo, M. (2014), Modelling asymmetric cointegration and dynamic multipliers in a nonlinear ARDL framework, [in:] R.C. Sickles, 
W.C. Horrace (eds.), Festschrift in Honor of Peter Schmidt, Springer, New York, pp. 281-314, https://doi.org/10.1007/978-1-4899-8008-3_9

Tabak, B.M., Serra, T.R., Cajueiro, D.O. (2009), The Expectation Hypothesis of Interest Rates and Network Theory: The Case of Brazil, "Physica A: Statistical Mechanics and its Applications", 388 (7), pp. 1137-1149, https://doi.org/10.1016/j.physa.2008.12.036 Thornton, D.L. (2014), Monetary Policy: Why Money Matters (and Interest Rates Don't), "Journal of Macroeconomics", 40, pp. 202-213, https://doi.org/10.1016/j.jmacro.20 13.12.005

Tronzano, M. (2018), The Expectations Hypothesis of the Term Structure in the Philippines: An Empirical Note (2001-2017), "Article in Asian Economic and Financial Review”, 8 (5), pp. 804-816, https://doi.org/10.18488/journal.aefr.2018.85.704.716

Van der Merwe, E., Mollentze, S. (2013), Monetary Economics in South Africa,

Velásquez-Giraldo, M., Restrepo-Tobón, D. (2016), Affine Term Structure Models: Forecasting the Yield Curve for Colombia, "Lecturas de Economia", 85 (28), pp. 53-90, https://doi.org/10.17533/udea.le.n85a02

Verheyden, T., De Moor, L., Van den Bossche, F. (2013), A Tale of Market Efficiency, "Review of Economic and Business Literature", 58 (2), pp. 139-156.

Walsh, C.E. (2003), Monetary Theory and Policy, 2nd Ed., The MIT Press, Cambridge.

\section{Analiza porównawcza hipotezy oczekiwań struktury terminowej stóp procentowych między krajami BRICS i G7}

W artykule dokonano analizy zdolności predykcyjnej hipotezy oczekiwań struktury terminowej stóp procentowych w krajach BRICS i G7, porównując miesięczną stopę oprocentowania trzymiesięcznych bonów skarbowych każdego kraju ze stopami oprocentowania 10-letnich obligacji skarbowych w okresie od maja 2003 do maja 2018. Model panelowy ARDL, wykorzystujący estymatory Mean Group (MG), Pooled Mean Group (PMG) i estymatory modelu dynamicznego z efektami stałymi (DFE), posłużył do porównywania krótko- i długookresowych relacji w obu grupach krajów. Wyniki pokazują, że hipoteza oczekiwań jest prawdziwa zarówno dla grupy krajów BRICS, jak i G7. W dłuższej perspektywie krótkoterminowa stopa procentowa pozwala przewidzieć długoterminową stopę procentową zarówno w krajach BRICS, jak i G7. Stopy procentowe w krajach BRICS wskazują na szybką korektę i powrót do długookresowej równowagi, podczas gdy w bloku G7 korekta następuje powoli. Powolne dostosowywanie się do równowagi w krajach grupy G7 sugeruje, że kryzys finansowy wpłynął na strukturę terminową stóp procentowych gdyż kraje G7 zostały bezpośrednio dotknięte kryzysem.

Słowa kluczowe: Hipoteza oczekiwań, model panelowy ARDL, G7, BRICS, struktura terminowa 